Meta

Journal des traducteurs

Translators' Journal

\title{
Terms and their LSP Environment - LSP Phraseology
}

\section{Heribert Picht}

Volume 32, numéro 2, juin 1987

Vers l'an 2000. La terminotique, bilan et prospectives

Objectives: Year 2000 Terminotics. State of the Art, Prospects for the Future

URI : https://id.erudit.org/iderudit/003836ar

DOI : https://doi.org/10.7202/003836ar

Aller au sommaire du numéro

Éditeur(s)

Les Presses de l'Université de Montréal

ISSN

0026-0452 (imprimé)

1492-1421 (numérique)

Découvrir la revue

Citer cet article

Picht, H. (1987). Terms and their LSP Environment - LSP Phraseology. Meta, 32(2), 149-155. https://doi.org/10.7202/003836ar d'utilisation que vous pouvez consulter en ligne.

https://apropos.erudit.org/fr/usagers/politique-dutilisation/ 


\section{TERMS AND THEIR LSP ENVIRONMENT — LSP PHRASEOLOGY}

HERIBERT PICHT

The Copenhagen School of Economics and Business Administration Frederiksberg, Danemark

\section{INTRODUCTION}

Most attempts to establish a distinction between LGP (Language for General Purposes) and LSP (Language for Specific Purposes), whether the approach selected be a structuralized, a semantic or a pragmatic one, are equally characterized by the presence of borderline areas which defy unambiguous classification as LSP according to the customary definitions. Admittedly, the past 5-8 years have witnessed impressive progress through the development of more finely differentiated models $1,2,3$, but it would be going too far to claim that the "twilight zones" which occur along the vertical and horizontal dividing lines have now been successfully eliminated. It seems that the "grey" zones - governed by subjective, and cognitive factors - still persist.

It is not my intention here to attempt a critical assessment of the current theories ; it should merely be pointed out right at the outset that, within the domain of LSP, extensive areas still lie unexplored, inviting further research. What I hope to be able to do here is to suggest a method which could lead to the reduction of the "twilight" zones, and to propose a possible form for the next stage on the journey towards the achievement of a more accurate determination of the nature of the phenomenon of LSP.

\section{LSP PHRASEOLOGY}

It is widely recognized today that any LSP (the language belonging to a special field) is characterized by, among other features, a particular terminology, i.e. the special vocabulary of the special field in question. At wordclass level this is realized through nouns and noun syntagmas, verbs, adverbs and adjectives, but also through numerals and prepositions. All these terminological elements interact within a text and are linked with other non-LSP elements by means of syntax (surface) and on the level of meaning, through semantic relations.

At the syntactic level it proved possible to indicate certain features characteristic of LSP (for example zero-occurrence of certain grammatical constructions).

At the semantic level such progress within the field of LSP has been less apparent. In view of this, it appears to me desirable, if it is hoped to come one step nearer to the solution of the LSP problem, also to investigate more thoroughly the syntactic and semantic contextual environment in which terms are embedded.

\subsection{PHRASEOLOGY}

A consultation of Th. Lewandowski's Linguistisches Wörterbuch ${ }^{4}$ reveals that no entry is to be found under the heading "Phraseologie". Under "Phraseologismus" we read :

Feste oder stehende Wortverbindung, formelhafte oder idiomatische Wendung, z.B. "ägyptische Finsternis, die Zelte abbrechen,...". Es handelt sich um Lexeme, die aus mehreren Wört- 
ern bestehen, zusammen aber eine Gesamtbedeutung tragen. Sie sind - sematische Einheiten, in denen alle Wörter phraseologisch gebunden sind (z.B. schwarz sehen)

- wortäquivalent

- meist historisch-sprachhistorisch motiviert.

It is extraordinary that this dictionary should not provide more complete information, especially when one considers the volume of literature on the subject of phraseology which has appeared in the course of the last few years, for example, the annotated review of literature in 5 parts (1976-1985) in "Muttersprache"5. This review clearly traces the dynamic development of this branch of linguistics over the past 5-8 years.

As a provisional rough extensional determination of the concept one could postulate that the object of phraseological research should include proverbs, idiomatic expressions, quotations, celebrated turns of phrase, single words with special meanings, all of which are investigated from a structuralist, psycholinguistic and pragmalinguistic angle - to date, however, no research which approaches the problem from the point of view of LSP has been recorded.

Consultation of Lewandowski under the heading "Phrase" reveals the fact that this term is employed to denote all the following : "1) Im Sinne von Satz. 2) Durch Intonation und Pausen markierte Einheit der Rede. 3) Im Sinne von Syntagma, auch von Satzglied."

While all these references and information hardly find any direct application in the treatment of this subject, it appears not without a certain justification, especially with a flexible interpretation of "Phraseologismus", to call the linguistic environment of a term "LSP phraseology".

\subsection{COLLOCATIONS}

The study of collocation had its origins, as did the study of phraseology, in LGP ; however, some studies of collocation with an LSP background have now been made ${ }^{6,7}$.

Considered from different points of view, collocation has been defined as a "lexical structural unit" (Cowie and Mackin) or as "lexical solidarities" (Coseriu), where such implicit questions arise as :

Which linguistic elements can be connected and why? (with which other linguistic elements ?)

- How do such connections arise, what are the factors which permit of prevent the occurrence of certain collocations?

The study of collocation is certainly valuable and has relevance for. LSP phraseology; its findings should prove even more useful for the study of LSP phraseology than phraseological studies have proved to date.

Yet to my mind the study of collocation still leaves unanswered certain questions of central relevance for LSP phraseology :

1. To what semantic influences/modifications are the linguistic elements which cluster around an LSP collocational nucleus, a term, subject ?

2. Is it, in fact, reasonable to posit a semantic influence or modification at all ?

3. Or are such elements clustered around an LSP collocational nucleus not in fact already independent LSP elements? 


\subsection{AN ATTEMPT TO DEFINE "LSP PHRASEOLOGY" AND THE "LSP PHRASE"}

On the basis of the above the "LSP phrase" might be provisionally defined as

a phrase whose nucleus is a term with which linguistic elements are connected which, by entering a semantic relationship with the term, undergo a modification of meaning which renders them capable of collocation with the term and of forming together with the term a lexical unit with an LSP meaning.

"LSP phraseology" would, accordingly, be defined as the LSP discipline which studies the syntactic connections and the semantic relationships, and also the semantic modifications of those linguistic elements which are capable of being combined with the nucleus (the term) or which may become capable of combination with it.

These provisional definitions are intentionally broad in conception, since there exists at present no adequate research for the provision of a more precise definition.

Some time ago an investigation was started by the author with the aim of establishing when and in what circumstances an LGP verb becomes a verb with LSP use. The research is as yet uncompleted ; however, the first observed tendencies will be presented here, because they could well open up new perspectives for both theory and practice.

\section{LGP VERB VERSUS LSP VERB}

Discussions about whether a verb may be a term have already been presented 8 ; a majority of authors regard an LSP verb as a term. It is, however, less clear when a verb begins to acquire.LSP characteristics. The extreme cases are easily isolated also here, e.g. "gehen" $\longrightarrow$ "gefriertrocknen". Even at word-semantic level it is clear to which category the verb belongs. But what happens in the case of

ziehen - einen Wechsel ziehen

schneiden - ein Gewinde schneiden

errichten - ein Testament errichten?

Intuitively or through linguistic insights one senses that the verbs have undergone certain changes, characteristic features of the verbs assume prominence, features which in LGP were either latent or absent.

Intuition and linguistic insights are however deceptive and inappropriate for adoption as media of analysis. The study referred to took as its point of departure a catalogue of problems which have arisen to a great extent through unanswered questions which have occurred in the course of practical terminology and LSP translation work.

The following questions were considered :

a) What semantic changes take place in an LGP verb when it occurs in an LSP context, and why?

b) What factors effect the semantic change?

- the context as a whole?

- the special field?

- the "Mitspieler" (in the sense in which the term is used by the Valenz grammarians) ?

c) Is it possible to recognize a semantic change already through syntactic features, e.g. transitivity-intransitivity-reflexivity?

d) Can all verbs, or only some, be influenced semantically?

- degree of influence?

- typology formation?

— category formation of "Mitspieler" ? 
e) Is it possible to systematize the verbs found to occur within one special field according to their meaning?

- does this result in systems of concepts or in sub-systems?

- what relations exist between the concepts (verbs)?

f) Is it possible to isolate categories of features which may be used to identify the meaning of a verb in a given special domain?

g) What possible consequence for terminography, LSP translation and perhaps also for computer-assisted translation may be envisaged?

To find answers to these questions, the following analytical steps were carried out on a corpus comprising 4115 Spanish verbs taken from the special language of mechanics. It is not my intention to present here a detailed account of the individual stages of the analytical process, but rather to offer an outline of the progress made so far. A more thorough description of the procedure followed may be found in $(9+10)$.

\subsection{THE PHASES OF THE ANALYSIS TO DATE}

In the analysis the point of departure taken was the actual structure of the genuine examples, i.e. the expression side, followed by a study of the semantic side, where terminological methods of analysis were adopted wherever appropriate.

\section{Syntactic analysis}

Here it was investigated what syntactic elements enter into a relationship with a verb (subject; object(s), prepositional elements, adverbials).

\section{Valenz analysis}

This phase of the analysis is subdivided into a syntactic and a semantic part. The bipartite character of Valenz analysis effects the transition between the introductory, syntactic phase and the central, semantic phase.

It was observed :

- which elements occur in which syntactic slots

- which pattern appears and where, with regard to a preliminary rough semantic classification.

Here the first differences in meaning became recognizable.

\section{Semantic analysis}

a) Establishment of the LGP meaning of a given verb

In this sub-phase, as might be expected, the first serious problems were encountered, as it proved impossible to exclude the subjectivity factor to a satisfactory degree. As a pragmatic solution the monolingual LGP dictionary "Diccionario de uso del Español" (Maria Moliner) was selected. The analysis of the dictionary entries revealed the difficulties which confronted the author, especially with respect to meaning which clearly belonged to the domain of LSP.

\section{b) Classification of "Mitspieler" in categories}

As far as the example material provided a sufficient basis for the operation, it was possible to register the existence of definite categories, in less pronounced cases the contours of categories could be noted.

c) Establishment of the shared characteristics of a verb in various shades of meaning

After the recognition of differences in meaning brought about by "Mitspieler", the shared characteristics still remaining were sought. It was observed that these characteristics also occurred extensively in the LGP meaning; they are in most cases extremely 
general and might be compared to those which are found in the intension of superordinate terms on a high hierarchic level.

d) Recognition of the distinguishing characteristics

In this phase the attention was directed towards those characteristics which are recognizable as differing in meaning from the basic meaning and as influenced/ occasioned by the presence of "Mitspieler". Here verbs appeared to be influenced to different degrees by the "Mitspieler". To date it has been possible to isolate three groups ( 1 . No change. 2. A certain change, but not connected to the subject field. 3. Marked change dependent on the subject field.).

e) Description of the individual meanings

On the basis of the distinctive characteristics the various meanings/shades of meaning dependent on the "Mitspieler" (categories) were described and re-compared to the dictionary in question.

As a provisional result it was noted that a not inconsiderable number of meanings are not to be found in the dictionary; neither did it prove possible to find them in other special dictionaries.

\section{f) Grammatical implications}

As the, so far, final semantic phase of the analysis an attempt was made to clarify the syntactic consequences of the semantic changes, which could result directly from the changes, e.g. the requirement of an explicit subject belonging to a certain category, "unusual" use of prepositions, single or double object, etc.

It appears rather too early in the day as yet to make any definite statement about future stages in the analytic process; but the preliminary findings suggest that at least some of the first questions will be able to be answered.

\section{CONSEQUENCE OF LSP PHRASEOLOGICAL ANALYSIS}

This analysis could be important for further work on both the theoretical and the practically-oriented level.

4.1 On the theoretical level it may lead to the reduction of the "grey areas" to which mention was made earlier; in other words, LSP, through the consideration of the phraseology of LSP as a relevant factor. The separation of terms on the one hand and the linking elements from LGP on the other may not be maitained uncritically. Whether such elements may then be characterized as "terms", if they meet the relevant requirements, or whether they must be graded according to conditions valid for them alone, for example, seen from a terminological point of view, must then be considered.

4.2 On the practically-oriented level the consequences are more concrete and more immediately apparent. LSP phraseology will have influence in the following areas :

- LSP translation and didactics

terminological analysis

terminographical representation

- machine translation.

\subsubsection{LSP translation}

It goes without saying that the correct translation of terms as central bearers of meaning is a sine qua non of LSP translation. Here the special dictionaries - as far as these are available - come to the aid of the translator. But the Achilles heel of the oper- 
ation remains the creation of the appropriate LSP environment for the term in the target language.

It is no secret that this problem remains unsatisfactorily dealt with even in translation carried out by professionals. How much greater the problems are for teaching is sufficiently well-known.

Special dictionaries are almost invariably inadequate when it comes to phraseological information - when, indeed, such information is even included. The translator is obliged to have recourse to texts in the target language which may prove helpful. But the method is time-consuming at best and reduces the translator's output.

\subsubsection{Terminological analysis}

For practical terminology work, which today focusses to a great extent on the term and the concept, LSP phraseology means a further dimension. More information must be gathered and analysed. Such an extensive analysis would then make greater demands, especially at the linguistic level, on the terminologist, and this development would bring in its train a more extensive training. On the other hand, the storage of such information, which could nowadays be undertaken with the help of termbanks, should now prove comparatively easy.

\subsubsection{The terminographical representation}

The inclusion of LSP phraseological information in dictionaries will raise one or two fundamental questions. Shoud the (most common) phraseological elements capable of combination with a term be supplied for every single term ? This method would probably lead to considerable redundancy. Or should the verbs from a particular special field be given separately - possibly together with the appropriate prepositions - perhaps with information about the categories of terms with which they may be used ? Is a form of systematic representation possible (as in the case of systems of concepts) or is an alphabetical list the only possible solution?

To these and other questions answers will need to be found.

\subsubsection{Machine translation (computer-assisted translation)}

Like the human translator, the machine will constantly encounter the problem of the choice of the appropriate LSP contextual environment for a term, but with the obvious difference that the machine is incapable of making intellectual and individual decisions. It must be provided with the input derived from the intellectual work prior to the job of translation. In short : the LSP phraseological problems at semantic and syntactic level must be solved before the operation may proceed at the programme level.

\section{CONCLUDING REMARKS}

It would be tempting to ask the fundamental question of whether the proper place of the study of LSP phraseology is within the domain of the theory of terminology, occupying as it undoubtedly does a position somewhere between the theory of terminology as defined by the Viennese and Soviet Russian schools, for instance, and the study of LSP in the widest sense of the term. In my own estimation there are a number of excellent reasons for regarding LSP phraseology as a part of the theory of terminology, not the least of which is the close relationship between LSP phraseology and the term which forms without question the nucleus of the LSP phrase and, moreover, forms the object of study within the framework of terminological analysis. 


\section{BIBLIOGRAPHY}

1. MÖHN, D., R. PELKA (1984) : Fachsprachen. Eine Einführung ; Germanische Arbeitshefte, Tübingen, M. Niemeyer Verlag.

2. v.HAHN, W. (1983) : Fachkommunikation. Entwicklung. Linguistische Konzepte. Betrieblich Beispiele, Berlin, New York, Walter de Gruyter.

3. HOFFMANN, L. (1984) : Kommunikationsmittel Fachsprache. Eine Einfiihrung; 2. überarbeitete Auflage, Berlin, Akademie-Verlag.

4. LEWANDOWSKI, Th. (1976) : Linguistisches Wörterbuch 1-3, Quelle \& Meyer.

5. DANIELS, K. Neue Aspekte zum Thema Phraseologie in der gegenwärtigen Sprachforschung, Teil 1-4 ; in : Muttersprache (1976) : pp. 257-293), (1979) : pp. 71-96, (1983) : pp. 142-170, (1984) : pp. 49-68.

6. FABER, D. (1984) : Kollokative mǿnstre. Specielt med henblik páø konomisk sprogbrug, manus, Handelshjskolen i Kbenhvn.

7. KÖHLER, C. (1985) : Verben in deutschsprachigen Fachtexten - Supplementverben; in : Fachsprache. Fremdsprache. Muttersprache, Heft 1, Technische Universität Dresden.

8. RENZ, S. (1971) : Zu einigen Problemen des Terminus; in : Muttersprache, pp. 304-312.

9. PICHT, H. : Hvadøgr et almensproget verbum til et fagsprogligt verbum - verbernes terminologisering ; in : AScLA-Symposiet "Oversttelse og Tolkning", 4.-6. oktober 1982; Fagsprogligt Center, 1983.

10. PICHT, H. : Termer og deres fagsproglige omgivelser - fagsproglig fraseologi ; in : Nordisk Terminologikursus II, bind 1, pp. 296-316, proceedings 1985. 